\title{
OCJENJIVANJE KUNIĆA
}

\author{
Almira Softić, Aida Kavazović, Aida Kustura, T. Kapitan
}

\begin{abstract}
Sažetak
Uzgoj kunića ima višestruki privredni i sportski značaj, kao i za hobi aktivnost. Vrijednost uspjeha svakog uzgajivača očituje se u uzgoju ljubimca i njegovog izlaganja na različitim izložbama gdje se vrši ocjenjivanje. Osnovica ocjenjivanja može biti izgled ili natjecateljski rezultati. Ocjenjivanje se vrši prema vanjskom izgledu životinje (fenotipu) imajući u vidu osobine određene pasmine propisane standardom, s ciljem unapređenja uzgojno - sportskih vrijednosti. Iako ima dovoljno objašnjenja o ovoj tematici u vidu različitih izvora informiranja, postoje nejasnoće pri ocjenjivanju. $U$ radu su detaljno objašnjene pozicije kod ocjenjivanja, te predstavlja stručni doprinos i pregled širem krugu zainteresiranih uzgajivača, stručnjaka praktičara i ljubitelja kunića.
\end{abstract}

Ključne riječi: ocjenjivanje, kunići

\section{Uvod}

Ocjenjivanje kunića izvodi se prema standardu za pojedinu pasminu. To je jedna od selekcijskih mjera kojom se ustanovljava vrijednost izložbenih jedinki i utvrđuju najbolje jedinke s obzirom na pasminu, eksterijer, razvoj, tjelesnu masu, kvalitetu krzna, dlake, vune i njegu kunića. Gotovo svaka zemlja ima neke specifičnosti u standardu koji primjenjuje, a najprimjetnije su razlike između američkog i europskog standarda, iako postoje razlike među standardima pojedinih europskih država (http://www.bihgolub.com/naslovna/index.php?view= article\&catid=13\%3 Apravilnici\&id=70\%3 Apravilnik-o ocjenjivanju).

Ocjenjivanje podrazumijeva prosudbu svakog dijela tijela koji se kasnije boduje. Životinje su podijeljene u skupine prema sličnim karakteristikama, odnosno prema obliku, krupnoći, porijeklu, boji i drugim pasminskim obilježjima. Da bi se ocijenio kunić potrebno je poznavati osobine u građi tijela ili eksterijer pojedine pasmine. Ocjena građe tijela vrši se opipavanjem ili vizualno ovisno o pasmini (Gjurić, 1985; Softić i sur., 2012, Kapitan, 2015). Osnova ocjenjivanja može biti izgled ili natjecateljski rezultati. Ocjenjivanje ima za cilj ukazati uzgajivačima na greške u uzgoju i eventualne promjene u standardu. Shodno tome u radu su prezentirane upute za ocjenjivanje pozicija i njihovih grešaka kod kunića.

Prof.dr.sc. Almira Softić, prof.dr.sc. Aida Kavazović, prof.dr.sc. Aida Kustura, Zavod za zootehniku i peradarstvo Veterinarski fakultet Univerziteta u Sarajevu, Zmaja od Bosne 90, 71000 Sarajevo, Bosna i Hercegovina; Tomislav Kapitan, predsjedink kunićarskog odbora Hrvatskog saveza udruga uzgajatelja malih životinja i delegat Hrvatskog saveza udruga uzgajatelja malih životinja u EE savezu sekcija kunićarstvo, Milke Trnine 15, 10310 Ivanić Grad, Hrvatska.

Dopisni autor/Corresponding author: Almira Softić; e-mail: almira.softic@vfs.unsa.ba 


\section{Pozicije za ocjenjivanje}

Da bi se ocijenio kunić potrebno je poznavati osobine u građi tijela ili eksterijer pojedine pasmine (slika 1)..
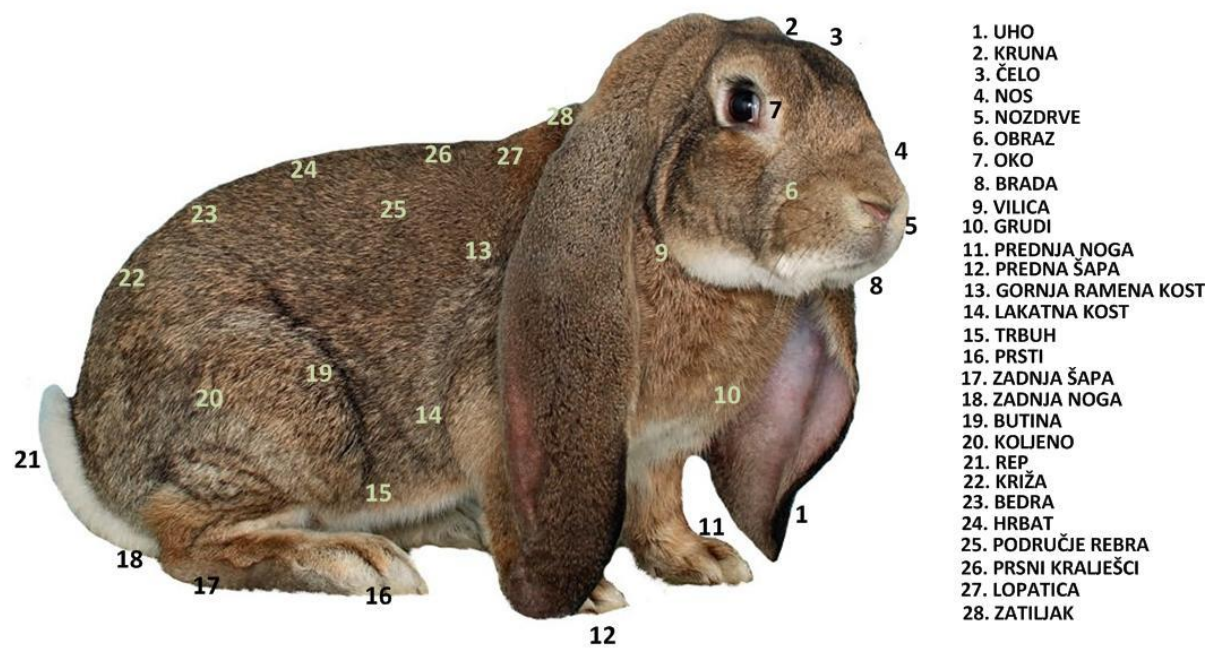

Slika 1. Prikaz pozicija pojedinih dijelova tijela kunića

Tip i oblik tijela svake pasmine podrazumijeva usklađenost pasminskog obilježja i proporcionalnost tijela, glave, ušiju i nogu. Gledajući prema spolu, muške i ženske jedinke se razlikuju. Kod mužjaka se bitne karakteristike očituju u širini, jakosti glave i tijela, izraženoj mišićavosti, dok su ženke finije i nježnije građe (Gjurić, 1985). Ova osnovna načela za ocjenjivanje građe tijela su mjerodavna za ocjenjivanje svih pasmina, dok ona u pojedinim opisima pasmina ne odstupaju od ovog standarda. Kod ocjenjivanja ukupnog utiska i tipa svih pasmina je bitna vizualna, ali i palpativna metoda ocjene. Tijelo treba biti srednje dužine, dobre građe i razvijenosti čiju osnovu čini čvrsti kostur, te s razvijenom muskulaturom daje pravi tip i oblik tijela životinje (slika 2.). Vrijednosti proporcije tijela trebaju iznositi širina=dubina $1 / 3$ tijela (Softić i sur., 2012). Treba znati razlikovati osnovne oblike oblici „nabijen“ i „,rastegnut“, te oblike „lagano nabijen“ $i$,lagano rastegnut, koji definiraju pasminu. Glava svake pasmine ima karakterističan oblik. Kod mužjaka svih pasmina glava je veća, široka i gruba. Kod ženki je glava manja, produžena i nježna. Idealan oblik glave bio bi jaka i kratka s širokim čelom i njuškom te manja presvođenost u nosnom profilu. Uši trebaju biti pravilno razvijene, mesnate, zaobljene, a veličina biti proporcionalna tijelu za pojedinu pasminu. Kod bijelog orijaša uši su duge, postavljene u obliku slova $\mathrm{V}$ (slika 4.). Ovnoliki kunići imaju duge, viseće uši, dok je ta karakteristika za druge pasmine greška. Ocjenjuju se u različitim pozicijama, kod pasmina koje imaju pozicije, ,glava/građa glave i ušiju“ odnosno pozicije „glava“ $i$, ,uši“. Vrat treba biti vrlo kratak, a glava sjedi gotovo na trupu (Kapitan, 2014). Trbuh treba biti spušten, malen i skladan. Podbradak ženki treba biti normalne veličine i svojstven pasmini koja se ocjenjuje, a kod 
mužjaka mali podbradak služi kao ukras. Prsa moraju biti široka i duboka. Leđa moraju biti ravna i široka, a leđna linija skladno razvijena, od potiljka do repa malo zaobljena. Prednje noge trebaju biti snažne i ravne, da drže tijelo iznad poda, a lopatice prilegnute uz tijelo. Zadnje noge trebaju biti snažne, ravne i priljubljene paralelno prema tijelu. Natkoljenice su mišićave, bez stršećih kostiju. Bedra su mišićava, bez uočljivih kostiju, a zdjelica dobro zaobljena, široka bez izbočenih kostiju kukova. Rep treba biti ravan i prilegnut prema tijelu, a koža dobro pripijena uz tijelo, elastična i nježna, u odnosu na mužjaka gdje je nešto grublja. Oči moraju odgovarati boji krzna i noktiju, a nokti trebaju da budu prilagođeni boji kunića. Dužina tijela mjeri se pomoću metra, od kraja nosa do korijena repa. Obim prsa određuje se pomoću trake, a obuhvaća dio iza lopatica. Određivanje starosti je dosta teško, jer se kod kunića ne može odrediti starost po trošenju zubala kao kod drugih domaćih životinja. Svako njihovo trošenje nadomješta se stalnim rastom. Odrasli kunić ima 28 zuba i to 6 sjekutića, jedan par donjih i dva para gornjih sjekutića (dva tzv. peg zuba iza sjekutića), zatim tri para pretkutnjaka u gornjoj vilici, dva para pretkutnjaka u donjoj vilici, i po tri para kutnjaka u obje vilice. Zubna formula je: 2 (I2 / 1 C0 / 0 M3 / 2) = 16 mliječnih zuba 2 (I2 / 1 C0 / 0 P3 / 2 M3 / 3) = 28 trajnih zuba. Spol kunića se može točno odrediti samo neposrednim pregledom spolnih organa (Kopanjski, 1988; Kapitan, 2006; Softić i sur., 2012) .
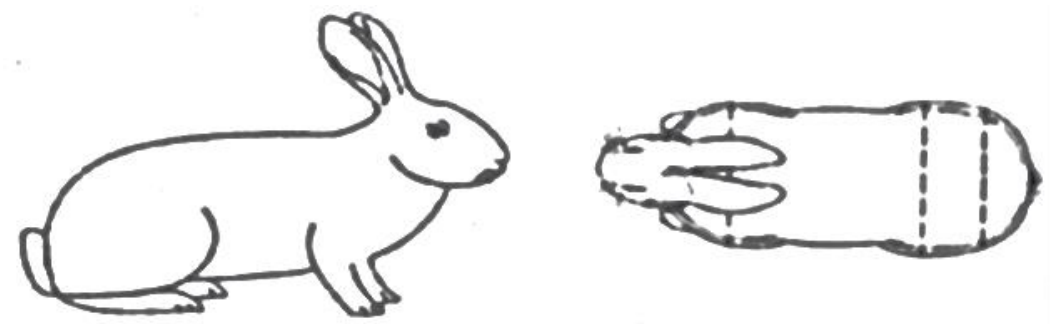

Slika 2. Idealan tip i oblik tijela (izvor: Softić i sur., 2012)

Lagane greške tipa i oblika tijela očituju se u manjem odstupanju od pravilnog tipa. Tu spada slijedeće: nježno građen mužjak, grubo i snažno građena ženka, odstupanje u proporcijama, šiljata njuška, usko čelo, loš nosni profil, tanke uši (loše zaobljene, lagano nagnute, slabo obraštene), jaki trbuh (srednje pasmine), veliki trbuh (velike pasmine), jaki čvor pod bradom mužjaka, uska prsa, slabo mišićava leđa, nesimetrična leđna linija, izbočene lopatice, slabe i tanke prednje noge, malo ogoljeni tabani, zadnje noge koje ne stoje parlelno s tijelom, izbočeni kukovi, malo krivi rep, viseći testisi (slike 3., 4., 5., 6.). 

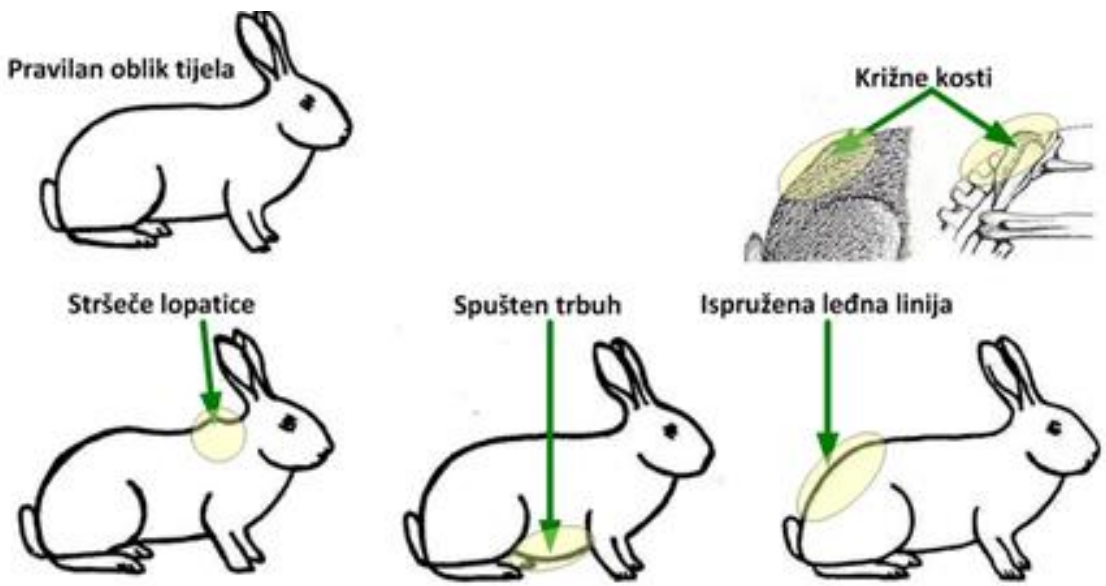

Slika 3. Lagane greške oblika tijela (izvor: Kapitan, 2014)
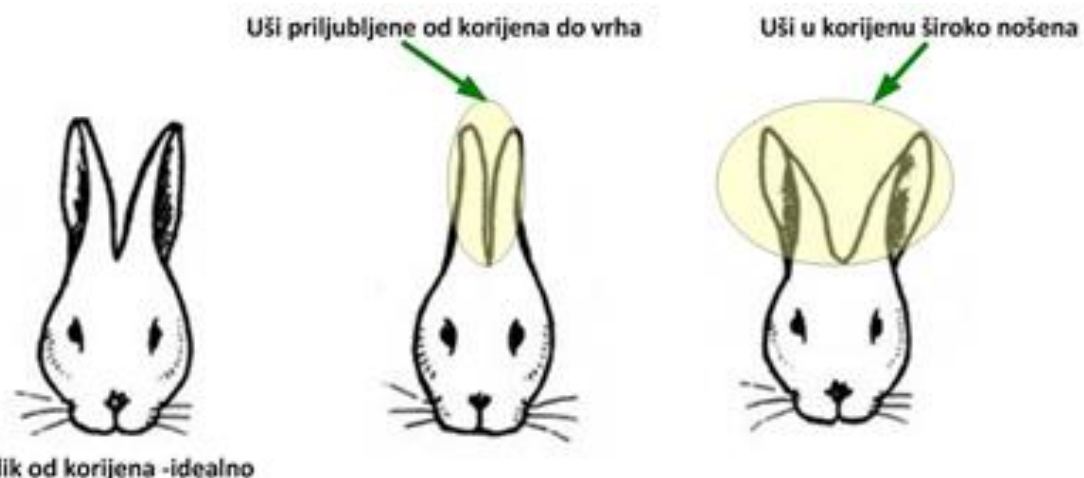

$\checkmark$ oblik od korijena -idealno

Slika 4. Lagane greške ušiju (izor: Kapitan, 2014)

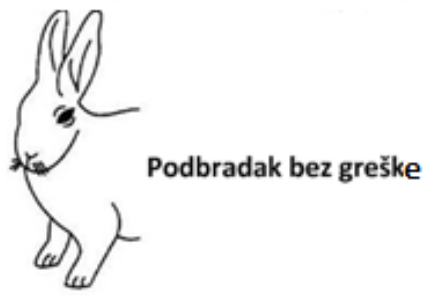

Dozvoljen podbradak (velike, srednje i neke male pasmine)

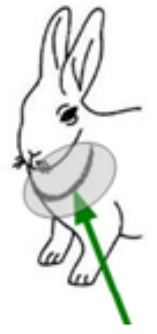

Lagane greške (velike, srednje i neke male pasmine)

Slika 5. Lagane greške podbratka (izvor: Kapitan, 2014) 


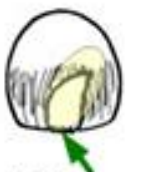

Krivi vrh repa
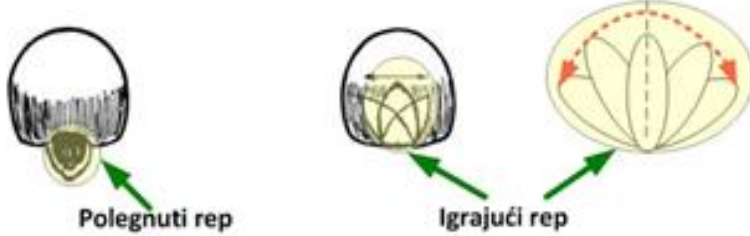

Slika 6. Lagane greške repa (izvor: Kapitan, 2014)

U teške greške tipa i oblika tijela spada veliko odstupanje u proporcijama, teške ozljede, nakaze, hermafrodit, nije u tipu, nepravilni zubi, viseće uši (osim ovnolikih kunića), čupavost, dostruki i kosi podbradak kod malih pasmina, a preveliki kod mužjaka svih pasmina, strmi zadnji kraj leđa, jako uvinuta stopala, O i X noge, displazija kukova, krivi rep, manjak jednog ili oba testesa, višebojna šarenica - mrena, izbuljene oči i sl. (slike 7., 8., 9., 10., 11., 12., 13., 14.).

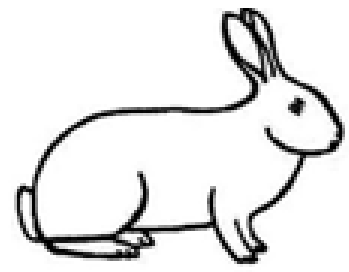

Pravilan oblik tijela
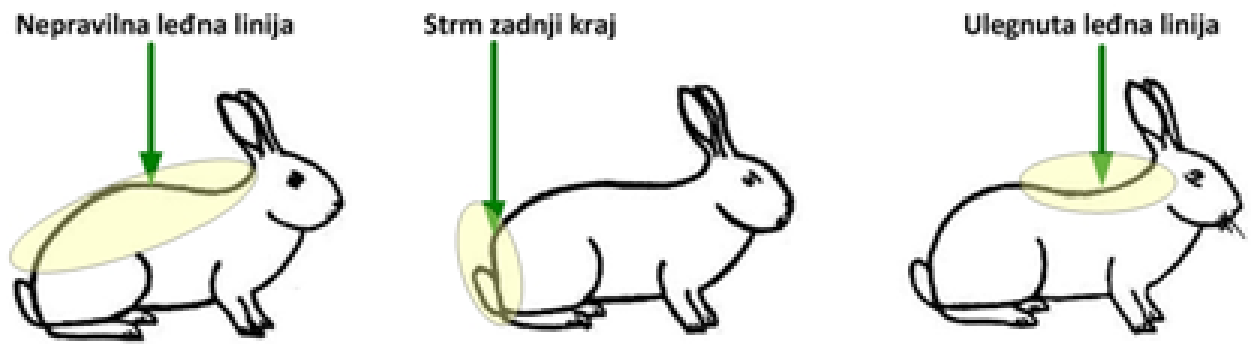

Slika 7. Teške greške oblika tijela (izvor: Kapitan, 2014)
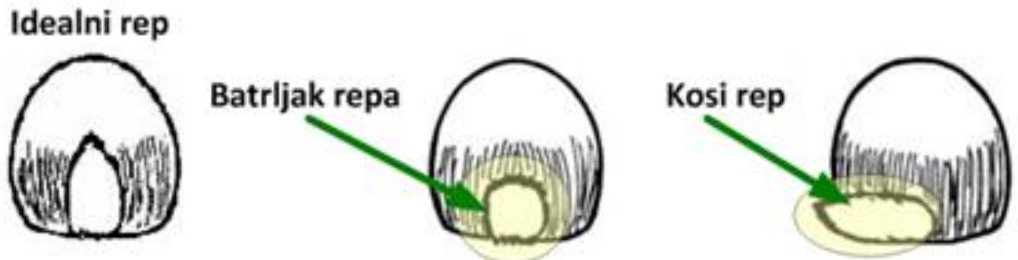

Slika 8. Teške greške repa (izvor: Kapitan, 2014) 


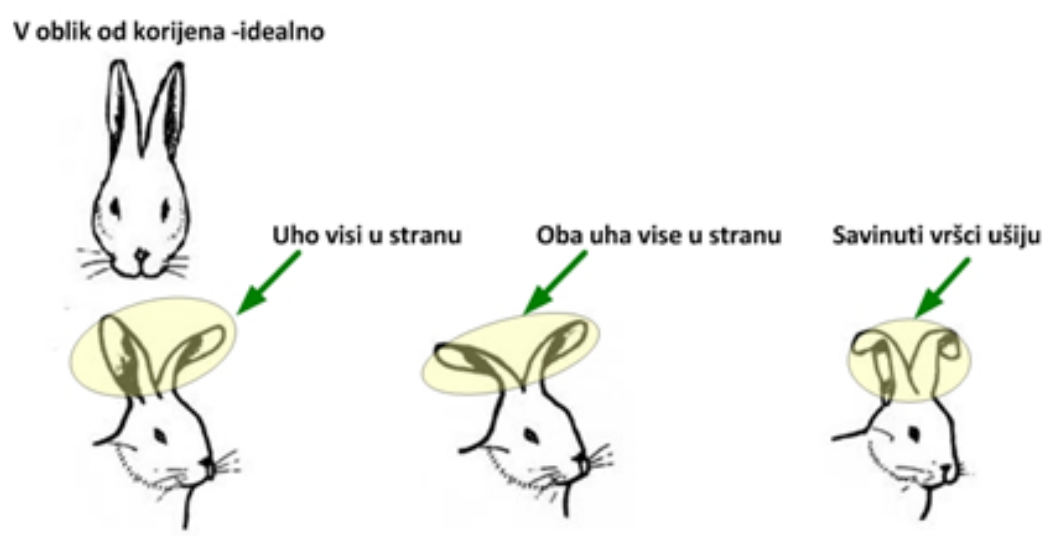

Slika 9. Teške greške ušiju (izvor: Kapitan, 2014; Softić i sur., 2012)
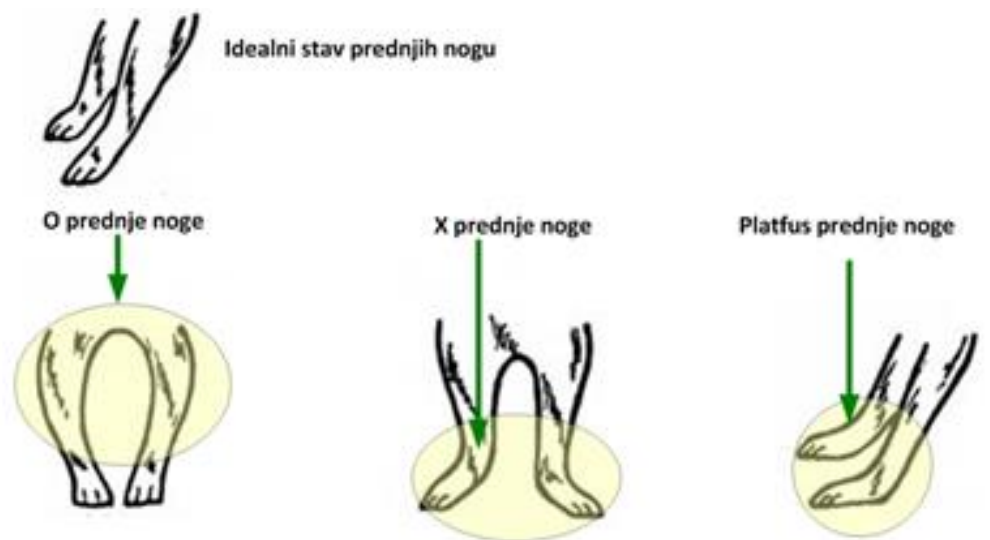

Slika 10. Teške greške prednjih nogu (izvor: Kapitan, 2014)

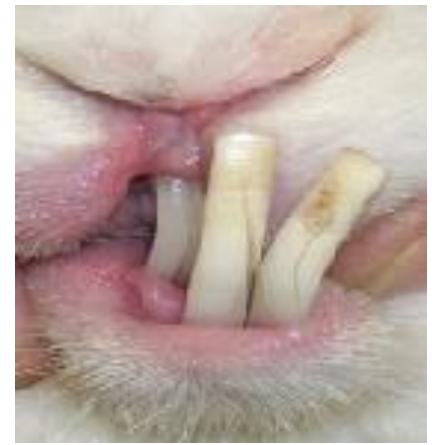

Slika 11. Teška greška zuba - prerasli zubi (izvor: Softić i sur., 2012) 


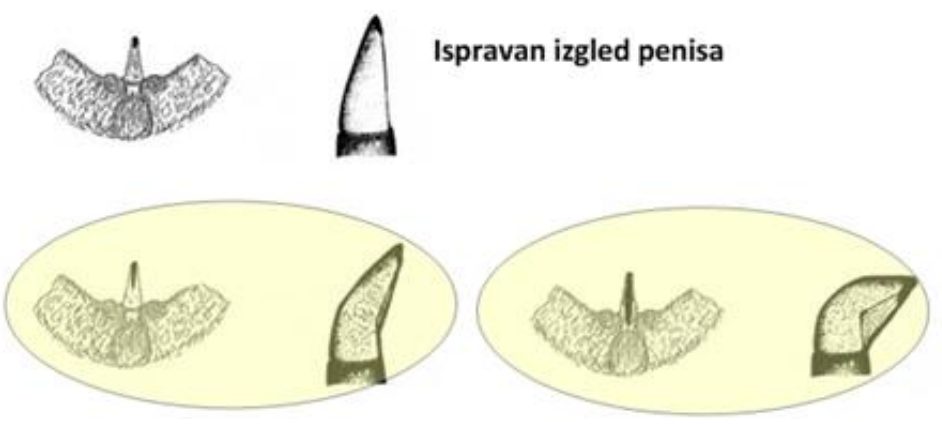

Slika 12. Teške greške penisa (izvor: Kapitan, 2014)

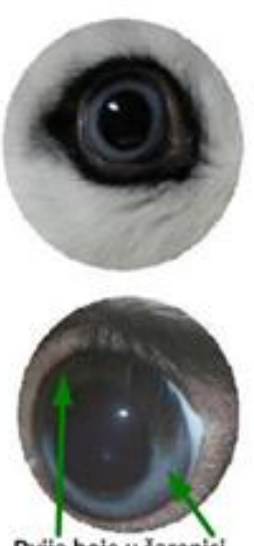

Dvije boje u Šarenici

Oko sa Šarenicom i lečom u boji

Slika 13. Teške greške očiju (izvor: Kapitan, 2014)

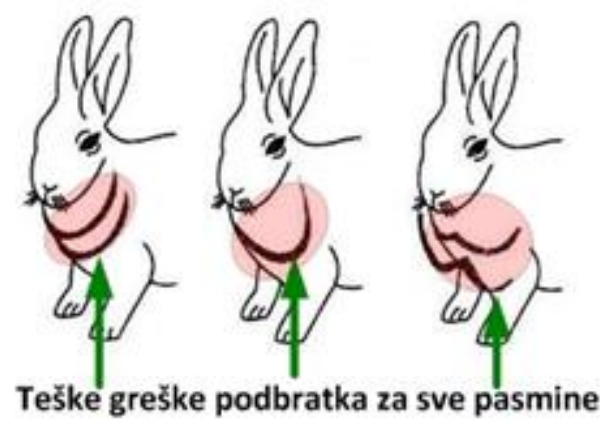

Slika 14. Teške greške podbratka (izvor: Kapitan, 2014)

Težina kunića određuje se vaganjem, a boduje se na osnovi tablice koja vrijedi za dotičnu pasminu. Ona ne smije biti puno veća od propisane, jer bi tako bila u disproporciji s pasminskom težinom i oblikom. Zbog toga ili pak ona težina ispod normalne se ne ocjenjuje (Gjurić, 1985). 
Krzno kunića sastoji od mnoštva dlaka različite visine i omjera u odnosu na dužinu, a razlikuju se po obliku, veličini i građi. Kod kunića postoje tri glavne vrste dlake, koje se razlikuju po obliku, veličini i građi (dugačka uspravna, osjata, i pahuljasta). Obzirom na veličinu razlikuje se normalna, kratka, duga i saten dlaka. Vrijednost životinje ocjenjujemo po gustoći donje dlake. Dobro krzno mora imati takvu pokrovnu dlaku koja nije ni pretvrda niti premekana, ili osjate dlake koje nadvisuju vunicu i daju krznu dobar sjaj. Kod kratkodlakih kunića, fina pokrovna dlaka smije svega jedan milimetar nadvisiti vunicu (donju dlaku), a vunica mora biti veoma gusta koja krznu daje baršunast izgled. Duga dlaka mora se ravnomjerno rasprostirati po cijelom tijelu i svilena je, dok je pokrovna dlaka pahuljasto mekana. Najbolje je dobro obrašteno krzno s dlakom bez ikavih ogoljelih mjesta. Kod saten dlake razrijeđenost strukture mora biti jednolična, a sjaj mora davati svileni odsjaj koji je trenutno uočljiv. Za procjenu kod takve dlake je bitna gustoća, tekstura, stopa povrata, ujednačenost, sjaj i stanje dlake (Kapitan, 2006). Lagane greške krzna očituje se krznom sa predugom ili prekratkom vunom, malo ćelava mjesta, loša kvaliteta dlake, malo slijepljeni izgled (filc). U teške greške krzna spada krzno sa jako malo temeljne vunice, manjak pokrovne dlake, oštra dlaka, jaka slijepljenost krzna (filc).

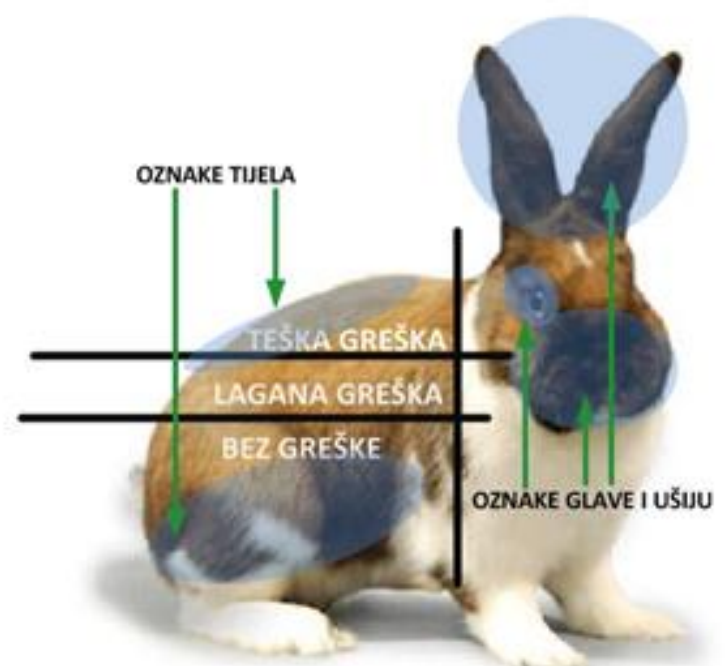

Slika 15. Oznake/crtež madagaskar meklenburškog kunića (izvor: Kapitan, 2014)

Pasminsko obilježje je u vezi s podgrupama kunića. Kod ocjenjivanja pojedinih pasminskih obilježja nalaze se podgrupe, a to su: jednobojne pasmine, pasmine s obilježjem, pasmine $\mathrm{s}$ crtežom, srebrenaste i biseraste pasmine, albino ili bijele pasmine i pasmine s strukturnom vunom. Te karakteristike opisuju opširno pasmine, dok su za boju važne njihove nijanse. Boja dlake i šare (crtež) moraju odgovarati pasmini kojoj pripadaju. Glavna ili pokrovna dlaka za svaku pasminu je svojstvena, koja po cijelom tijelu mora biti jednolična i bez primjesa drugih boja. Međuboja i donja boja, kao i donja dlaka (kvalitet vunice) treba biti da bude jednolična i bez primjesa drugih boja, a utvrđuje se puhanjem u krzno na križima pri čemu se vidi dno rozete 
ili lijevak boja. Kod pasmina, kojima su šarenilo ili crtež svojstveni, moraju biti oštro odvojeni od glavne pokrovne boje. Kod bijelih kunića nokti su bez boje, a kod obojenih tamni. Navedene podgrupe pasmina na osnovu pasminskog obilježja (oznaka, crtež, boja) imaju svoje lagane i teške greške (slika 15.). Neki primjeri lakših i težih grešaka za poziciju oznake i pokrovna boja i sjaj prezentirani su kod bijeloopaljenog kunića (slika 16. i 17.).

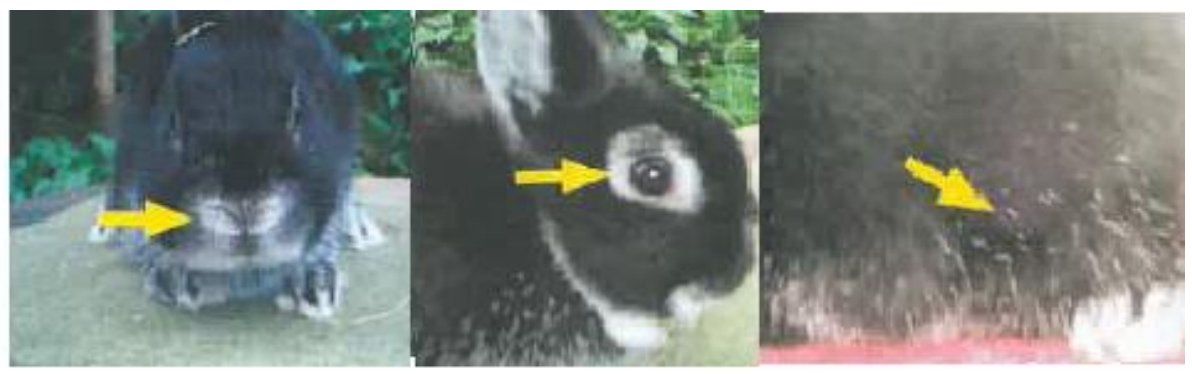

Šarena prošarana njuška Isprekidana obočnica očiju

Slabije neravnomjerno podjeljenje dlake po tijelu

Slika 16. Lagane greške u oznakama bjeloopaljenog kunića (izvor: Kapitan, 2014)
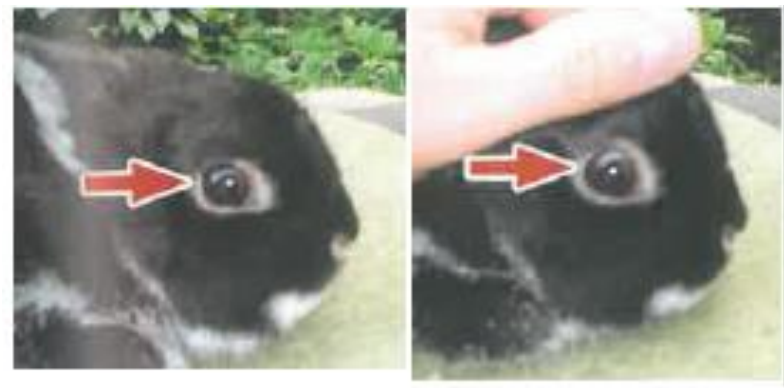

Prekid ili izostanak obočnice na očima

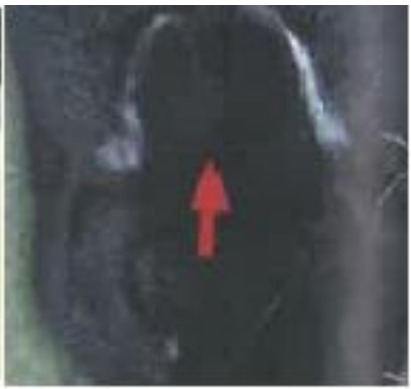

Izostanak okvira na ušima

Slika 17. Teške greške u oznakama bjeloopaljenog kunića

Zdravlje i njega je vrlo značajna pozicija pri ocjenjivanju i samo zdravi i njegovani kunići se mogu ocjenjivati. Visoko vrijedna životinja se očituje čistim nogama (šape), ušima, spolnom organu, dobro podrezanim noktima, sjajnim i kvalitetnim krznom, kao i živahnom temperamentu. Uz konačnu ocjenu važna važna je i ispravna tetovacija radi identifikacije. Ženke kunića u drugoj polovini gravidnosti se ne ocjenjuju. Ova je pozicija kod ocjenjivanja vrlo bitna za rasplodne kuniće, kao i konstitucija, kondicija, dob, težina, izgled i kvalitet krzna. Zdravlju i konstituciji pripada velika važnost s obzirom na nasljedne greške, dok je kondicija u vezi s težinom (Softić i sur., 2012). 


\section{Zaključak}

Vrijednost uspjeha svakog uzgajivača očituje se u uzgoju ljubimca i njegovog izlaganja na različitim izložbama gdje se vrši njegovo ocjenjivanje. Iako ima dovoljno objašnjenja o ovoj tematici u vidu različitih izvora informiranja, postoje nejasnoće pri ocjenjivanju. U radu su detaljno objašnjene pozicije kod ocjenjivanja i predstavlja stručni doprinos i pregled širem krugu zainteresiranih uzgajivača, stručnjaka praktičara i ljubitelja kunića.

\section{LITERATURA}

1. Gjurić, A. ( 1985.: Kunićarstvo. Nakladni zavod Znanje. Zagreb.

2. Kapitan, T. (2006): Kunićarstvo i standard kunića. Nova knjiga Rast. Zagreb

3. Kapitan, T. (2014): Nasljeđivanje pasminskih obilježja kunića. Nova knjiga Rast. Zagreb

4. Kapitan, T. (2015): Ocjenjivanje kunića. Bilten hrvatskog saveza udruga uzgajatelja malih životinja, br. 53.

5. Kopanjski, R. (1988): Uzgoj kunića. Nolit. Beograd.

6. Pravilnik o ocjenjivanju. Savez za uzgoj i zaštitu sitnih životinja Bosne i Hercegovine (citirano 10. 11. 2016). Dostupno na: http://www.bihgolub.com/naslovna/index.php?view=article\&catid= 13\%3Apravilnici\&id=70\%3Apravilnik-o-ocjenjivanju\&option=com_content\&Itemid=37)

7. Softić, A., V. Katica, F. Alibegović-Zečić, A. Kavazović, M. Varatnović (2012): Uzgoj kunića. Izd. Veterinarski fakultet Univerziteta u Sarajevu. Sarajevo.

\section{EVAULATION OF RABBIT}

\section{Summary}

Breeding rabbit has multiple significance by the hobby, a sport and a economic. The value of the success of every breeder is reflected in the growing pet and its exposure to the various exhibitions where it is being assessment. The basis of assessment may be appearance or competition results. The evaluation is carried out according to the external appearance of animals (phenotype) taking into account the characteristics of certain breeds of prescribed standards, with the aim of improving breeding - sporting value. Although there is enough explanation on this subject in the form of different sources of information, there is uncertainty in the assessment. The paper explained in detail the position in the assessment, as well as a scientific contribution to the review of a wider range of interested farmers, practitioners and owner pet of rabbits.

Key words: evaluation, rabbits

Primljeno - Received: 21.11.2016.

Prihvaćeno - Accepted: 16.01.2017. 